\title{
Early phosphatemia changes in acute cardiac care patients
}

\author{
Jitka Lhotská, Vratislav Pechman, Jakub Čech, Jan Opatrný, \\ Milan Hromádka, Richard Rokyta jr.
}

\author{
Kardiologické oddělení, Komplexní kardiovaskulární centrum, Lékařská fakulta Plzeň, Univerzita Karlova v Praze \\ a Fakultní nemocnice Plzeň, Plzeň, Česká republika
}

\section{INFORMACE O ČLÁNKU \\ Historie článku: \\ Došel do redakce: 18. 3. 2012 \\ Přepracován: 11. 4. 2012 \\ Prijiat: 17. 4. 2012 \\ Publikován online: 25. 4. 2012}

Keywords:

Acute cardiac care

Acute coronary syndrome

Acute myocardial infarction

Cardiac biomarkers

Phosphatemia

Phosphorus

Kličová slova:

Akutní infarkt myokardu

Akutní kardiologická péče

Akutní koronární syndrom

Fosfatemie

Fosfor

Srdeční biomarkery

\begin{abstract}
Introduction: The significance of inorganic serum phosphate levels (Pi) in patients with acute coronary syndromes (ACS) in the reperfusion era is unknown, as well as its relation to biomarkers of myocardial necrosis. Our aim was to assess admission Pi and its dynamics in patients admitted to the intensive cardiac care unit (ICCU), with emphasis on patients with ST segment elevation myocardial infarction (STEMI).

Methods: We studied 192 patients admitted to the ICCU during a 4-month period. The first group included 92 patients with STEMI (STEMI group) treated by primary percutaneous coronary intervention ( $\mathrm{PCl})$. The second group consisted of 100 patients without ACS (non-ACS group). Normophosphatemia was defined as Pi 0.7-1.6 mmol/l. Phosphatemia was measured at admission and then 6 and 12 hours later as well as troponin I. Results: Admission phosphatemia was lower in the STEMI group as compared to the non-ACS group (Pi $0.95 \mathrm{mmol} / / \mathrm{l}$ v. $1.18 \mathrm{mmol} / \mathrm{l}, p<0.001)$. Admission hypophosphatemia $(\mathrm{Pi}<0.7 \mathrm{mmol} / \mathrm{l}$ ) was more often present in the STEMI group than in the non-ACS group $(21 \%$ vs. $4 \%, p=0.001)$. In all hypophosphatemic STEMI patients, serum Pi normalized itself within 6 hours without substitution. Admission hyperphosphatemia ( $\mathrm{Pi}>1.6 \mathrm{mmol} / \mathrm{l})$ was more frequent in non-ACS group (6.5\% STEMI pts. vs. $13 \%$ non-ACS pts.). In the STEMI group, admission phosphatemia did not correlate with peak troponin I.

Conclusion: We conclude that patients with STEMI treated by primary PCI have lower Pi and more frequent transient hypophosphatemia at admission than acute cardiac care patients without acute coronary syndrome.

SOUHRN

Úvod: Význam sérové koncentrace anorganického fosfátu (Pi) u pacientů s akutními koronárními syndromy (AKS) léčených mechanickou reperfuzí není známý, stejně jako její vztah k biomarkerům myokardiální nekrózy. Naším cílem bylo zhodnotit vstupní Pi a její dynamiku u pacientů přijatých na kardiologickou jednotku intenzivní péče (K-JIP), se zaměřením na nemocné s infarktem myokardu s elevacemi úseku ST (STEMI). Metody: Do studie bylo zařazeno 192 pacientů přijatých na K-JIP během čtyř měsíců. První skupina zahrnovala 92 nemocných se STEMI (skupina STEMI), kteří byli léčeni primární perkutánní koronární intervencí ( $\mathrm{PCI})$. Druhá skupina se skládala ze 100 pacientů bez AKS (skupina non-AKS). Normofosfatemie byla definována jako Pi 0,7$1,6 \mathrm{mmol} / \mathrm{l}$. Fosfatemie byla měřena při přijetí a následně po 6 a 12 hodinách, stejně tak i koncentrace troponinu I. Výsledky: Vstupní fosfatemie ve skupině STEMI byla ve srovnání se skupinou non-AKS nižší (Pi 0,95 mmol/l vs. $1,18 \mathrm{mmol} / \mathrm{l}, p<0,001)$. Hypofosfatemie při přijetí ( $\mathrm{Pi}<0,7 \mathrm{mmol} / \mathrm{l})$ byla častěji př́tomna ve skupině STEMI oproti skupině non-AKS ( $21 \%$ vs. $4 \%, p=0,001)$. U všech pacientů se STEMI, kteří měli hypofosfatemii, se sérová Pi normalizovala během šesti hodin, aniž by proběhla její substituce. Vstupní hyperfosfatemie (Pi > 1,6 mmol/l) byla častější ve skupině non-AKS (6,5 \% pacientů se STEMI vs. $13 \%$ pacientů bez AKS). Ve skupině STEMI vstupní fosfatemie nekorelovala s vrcholovým troponinem I.

Závěr: Naše výsledky ukazují, že nemocní se STEMI léčení primární perkutánní koronární intervencí mají při přijetí nižší fosfatemii a častější přechodnou hypofosfatemii ve srovnání s pacienty s akutním kardiologickým onemocněním bez akutního koronárního syndromu.
\end{abstract}

( 2012, ČKS. Published by Elsevier Urban and Partner Sp. z o.o. All rights reserved.

Adresa: MUDr. Jitka Lhotská, Kardiologické oddělení, Komplexní kardiovaskulární centrum, Lékařská fakulta Plzeň, Univerzita Karlova v Praze a Fakultní nemocnice Plzeň, alej Svobody 80, 30460 Plzeň, e-mail: Ihotskaj@fnplzen.cz

DOI: 10.1016/j.crvasa.2012.04.002 


\section{Background}

Normal organ function and many metabolic processes are dependent on intracellular as well as on extracellular electrolyte concentrations. Phosphorus is an essential element, majority (about $80 \%$ ) is a part of bones and teeth. $9 \%, 11 \%$ and $0.1 \%$ is found in skeletal muscle, viscera and extracellular fluid, respectively [1]. Both organic and inorganic phosphate are present in the blood. $85 \%$ of the inorganic form are free phosphate ions, $10 \%$ is bound with proteins and $5 \%$ with other minerals. Phosphorus has an important role in acid-base homeostasis maintenance, cellular and subcellular metabolism (e.g. cellular signal transduction, energy exchange) and in the cell structure as a component of the cell membranes lipid bilayer. Most intracellular phosphate is a component of creatine phosphate, adenosine triphosphate (ATP, the store of biochemical energy) and 2,3-diphosphoglycerate (2,3-DPG, the $\mathrm{O}_{2}$ release to tissue from red cells). The most important regulator of the phosphate plasma concentration are kidneys, the renal tubules reabsorbing approximately $80-90 \%$ of the filtered phosphate.

Hypophosphatemia is usually categorized as moderate (Pi $0.3-0.7 \mathrm{mmol} / \mathrm{l})$ or severe $(\mathrm{Pi}<0.3 \mathrm{mmol} / \mathrm{l})$. Moderate hypophosphatemia occurs in $2.2-3.1 \%$ of hospitalized patients [2-4], severe hypophosphatemia in $0.2-0.4 \%$ of patients $[2,4-6]$.

In intensive care unit patients, hypophosphatemia can be caused by multiple factors, e.g. sepsis, trauma, fluid therapy, etc. $[1,2,7]$. The most feared clinical consequences of severe hypophosphatemia are rhabdomyolysis, hemolysis, leukocyte dysfunction, perturbed nervous system, respiratory failure and heart dysfunction $[1,2,8,9]$. Severe hypophosphatemia is typically present in alcoholics, septic patients, patients with malnutrition and diabetic ketoacidosis and is associated with a higher mortality rate $[6,10]$.

Conversely, it has been shown that higher levels of serum phosphate have an independent positive association with the angiographic severity of coronary artery disease (CAD) and with the risk of myocardial infarction or death in patients with ischemic heart disease $[11,12]$.

Data about the incidence and role of serum phosphorus abnormalities in acute cardiac patients are scarce, in patients with acute myocardial infarction mostly from the prereperfusion era $[13,14]$. Our aim was to assess admission serum inorganic phosphate $(\mathrm{Pi})$ levels and its early dynamics in patients admitted to the intensive cardiac care unit (ICCU), in particular in patients with ST segment elevation myocardial infarction (STEMI) as well as its potential relation to biomarkers of myocardial necrosis and other minerals.

\section{Methods}

The study followed the principles established in the Declaration of Helsinki. The protocol was approved by the local ethics committee of University Hospital PIzen and all patients provided written informed consent. We prospectively evaluated consecutive patients admitted to the ICCU during a 4-month period (at the end of the year 2008). The first group included patients with acute myocardial infarction with ST segment elevation (STEMI group) and the second group comprised patients admitted to the ICCU without acute coronary syndrome (nonACS group). STEMI was diagnosed in the presence of chest pain, diagnostic electrocardiographic changes with characteristic ST segment elevation and elevated troponin I level. All patients in the STEMI group received standard antithrombotic therapy (clopidogrel, acetylsalicylic acid, unfractioned heparin) before baseline laboratory, underwent urgent coronary angiography and were treated by primary percutaneous coronary intervention ( $\mathrm{PCI})$.

Serum inorganic phosphate was measured using a standard photometric method (OSR 6122/6222, Beckman Coulter, analyser Olympus AU 640 or AU2700, Ireland) at the admission and then 6 and 12 hours later as well as cardiospecific enzymes - troponin l, creatine kinase and myoglobin. Troponin I was measured using the AccuTnI Beckman method, Reagent Catalog 33340 (Abbott, USA).

Normophosphatemia was defined as serum inorganic phosphate level 0.7-1.6 mmol/l. Phosphorus and calcium were administered neither parenterally nor enterally during the study period.

\section{Statistical analysis}

Data are means + standard deviation unless otherwise stated. Statistical comparison of the groups was performed by the chi-square test and Wilcoxon rank sum test. The $p<0.05$ was considered as statistically significant. We compared baseline characteristics of all patients. Then we compared $\mathrm{Pi}$ at admission and at 6 and 12 hours afterwards in both groups. In addition, we assessed the possible association of $\mathrm{Pi}$ with peak troponin I levels as well as with admission levels of calcium, potassium and magnesium.

\section{Results}

Complete data were obtained in 192 patients (M/F 129/63, mean age $66 \pm 13$ years). Acute myocardial infarction with ST segment elevation as the primary diagnosis was present in 92 patients (STEMI group); 100 patients had other acute cardiac disease (non-ACS group), e.g. arrhythmias, heart failure, pulmonary embolism, etc.

There were no statistically significant differences in baseline demographic data or in cardiovascular risk factors between groups except the known history of coronary artery disease (CAD) and heart failure (Table 1). Mean serum creatinine levels did not differ either.

Hyperphosphatemia at admission was more frequently present in the non-ACS group, whereas hypophosphatemia at admission was more frequent in STEMI patients (Fig. 1). The dynamics of $\mathrm{Pi}$ in both groups are shown in Fig. 2. There was no statistically significant difference in phosphatemia after 6 hours. Phosphatemia was significantly lower in STEMI group 12 hours after admission.

In all hypophosphatemic STEMI patients, serum Pi normalized itself within the first 6 hours (increase of Pi by $0.16 \pm 0.29 \mathrm{mmol} / \mathrm{l})-$ Fig. 3 . 
Table 1 - Baseline characteristic.

\begin{tabular}{|lccc} 
& STEMI group (92 pts.) & Non-ACS group (100 pts.) & Statistical significance \\
\hline Age (years) & $66( \pm 11)$ & $66( \pm 14)$ & $\mathrm{ns}$ \\
\hline Males/Females & $65 / 27(71 / 29 \%)$ & $64 / 36(64 / 36 \%)$ & $\mathrm{ns}$ \\
\hline Hypertension & $64(70 \%)$ & $66(66 \%)$ & $\mathrm{ns}$ \\
\hline Dyslipidemia & $40(43 \%)$ & $43(43 \%)$ & $\mathrm{ns}$ \\
\hline Diabetes mellitus & $25(27 \%)$ & $31(31 \%)$ & $\mathrm{ns}$ \\
\hline Smokers (incl. former smokers) & $48(56 \%)$ & $\mathrm{ns}$ \\
\hline PAOD & $5(5 \%)$ & $\mathrm{ns}(45 \%)$ & $\mathrm{ns}$ \\
\hline $\begin{array}{l}\text { Renal insufficiency } \\
\text { (baseline creatinin }>130 \text { mmol/l) }\end{array}$ & $30(32 \%)$ & $33(33 \%)$ & $\mathrm{ns}$ \\
\hline BMl & & $28.0( \pm 6.4)$ & 0.04 \\
\hline CAD & $27.2( \pm 3.8)$ & $35(35 \%)$ & 0.01 \\
\hline Heart failure & $20(22 \%)$ & $22(22 \%)$ & \\
\hline
\end{tabular}

Data are number $(\%)$ or mean $( \pm S D)$.

$\mathrm{BMI}$ - body mass index; CAD - coronary artery disease; non-ACS - patients without acute coronary syndrome; PAOD - peripheral artery occlusion disease; STEMI - patients with ST elevation myocardial infarction.

There were no statistically significant differences in calcium, potassium and magnesium level at admission in both groups (calcium $2.3 \pm 0.15 \mathrm{mmol} / \mathrm{l}$ in the STEMI group vs. $2.3 \pm 0.16 \mathrm{mmol} / \mathrm{l}$ in the non-ACS group, potassium $4.1 \pm$ $0.5 \mathrm{mmol} / \mathrm{l}$ in the STEMI group vs. $4.4 \pm 0.8 \mathrm{mmol} / \mathrm{l}$ in the non-ACS group, magnesium $0.9 \pm 0.3 \mathrm{mmol} / \mathrm{l}$ in the STEMI group vs. $0.9 \pm 0.1 \mathrm{mmol} / \mathrm{l}$ in the non ACS group). We found no correlation between admission phosphatemia and other laboratory parameters (admission serum total calcium level in STEMI patients $r=0.04, p=0.7074$, serum potassium level in STEMI patients $r=0.05, p=0.6185$ and serum magnesium level in STEMI patients $r=0.20$,

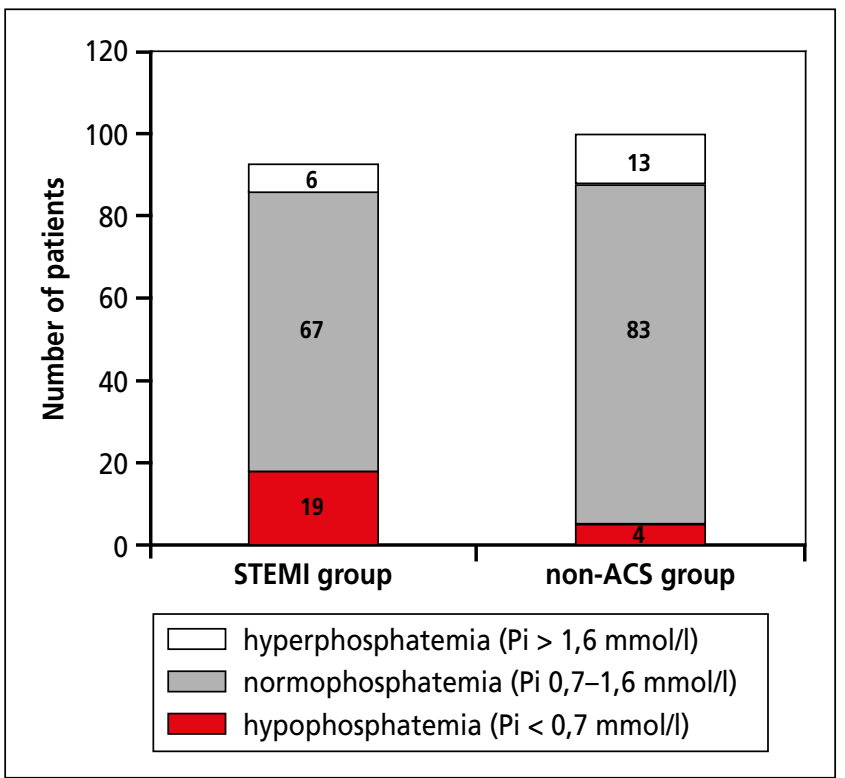

Fig. 1 - Phosphatemia at hospital admission.

non-ACS group - patients without acute coronary syndrome; STEMI group - patients with ST segment elevation acute myocardial infarction. $p=0.0743$ ). In STEMI group, admission phosphatemia did not correlate with peak troponin I (in STEMI patients $r=0.08, p=0.4640$ ).

\section{Discussion}

The main finding of our study was that STEMI patients have lower serum phosphate levels at admission than acute cardiac patients without acute coronary syndrome (ACS). In those STEMI patients with initial hypophosphatemia, serum Pi levels normalized within hours without exogenous phosphate administration.

The cause of hypophosphatemia in patients with ACS might be the acute stress response, which requires

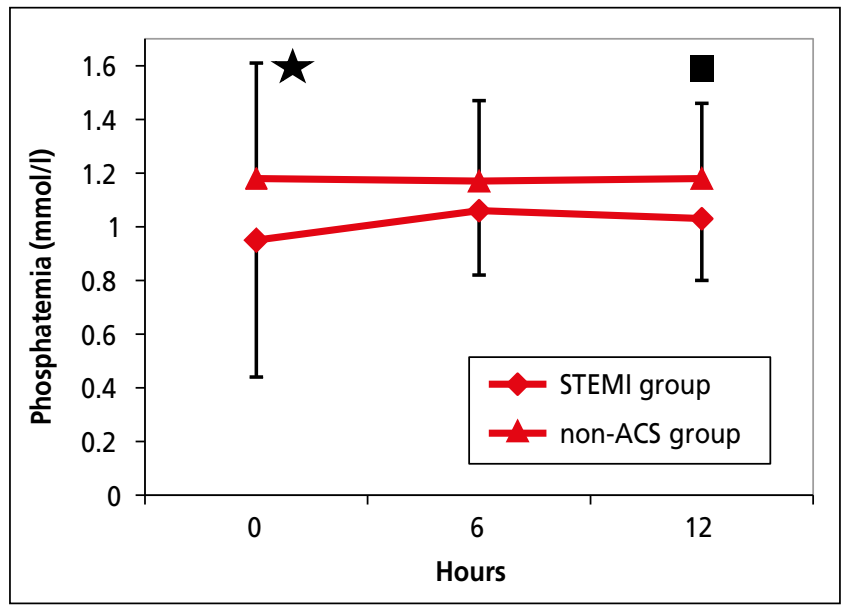

Fig. 2 - Time course of phosphatemia.

$\star p<0.001$ (difference between the groups at admission);

$\square=0.005$ (difference between the groups after 12 hours);

non-ACS group - patients without acute coronary syndrome; STEMI group - patients with ST segment elevation acute myocardial infarction. 


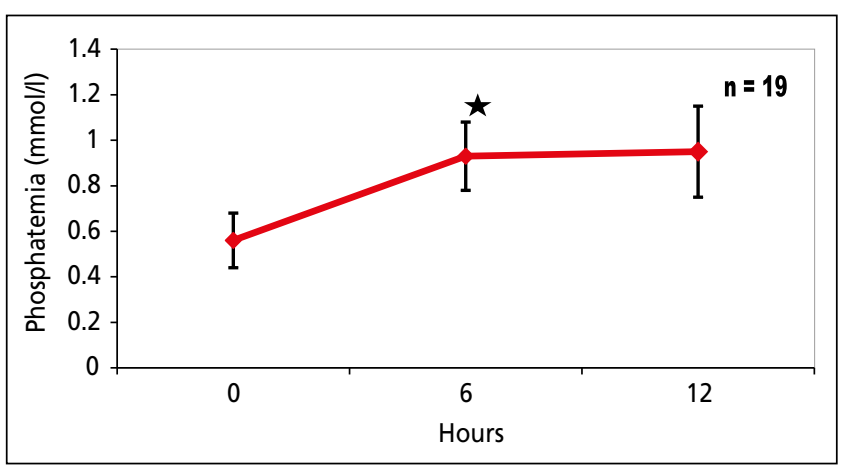

Fig. 3 - Time course of Pi in STEMI with admission hypophosphatemia. n - number of patients; Pi - phosphatemia; STEMI - myocardial infarction with ST segment elevation; $\star p<0.05$ (difference vs. baseline).

more energy and causes redistribution of phosphate into intracellular space, where Pi may be transformed into adenosine triphosphate and bind into damaged cell membranes of necrotic myocardial cells. It has been documented that hypophosphatemia may be the consequence of elevated serum catecholamine levels (endogenous or exogenous epinephrine and norepinephrine) or metabolic acidosis, which induces increased urinary loss of phosphate $[2,15]$. In the present study, we measured neither serum catecholamines nor arterial $\mathrm{pH}$ in a systematic way. Another limitation of our study was that we did not measure ionized calcium, serum vitamin D or parathormone levels.

It is known that the levels of Pi are mainly influenced by renal function. In our study, however, the incidence of renal insufficiency did not differ between the groups. Serum phosphate may also decline after acetylsalicylic acid administration. Acetylsalicylic acid has a protective effect on myocardial high energy phosphates during ischemia and reperfusion [13] and reduces $P i$ indirectly through the development of respiratory alkalosis $[16,17]$ and glycolysis is stimulated with intracellular phosphate shift. As all our STEMI patients received acetylsalicylic acid before baseline phosphate measurement, the effect of acetylsalicylic acid may be one of the reasons why we found lower phosphatemia in the STEMI group as compared to heterogenous group of non-ACS patients but explains neither the differences inside the STEMI group nor the dynamics of Pi changes.

Another potential cause of hypophosphatemia may be the intravenous administration of glucose and insulin stimulating carbohydrate metabolism and causing intracellular phosphate transport together with glucose mostly into the liver and skeletal muscle cells [15]. Nevertheless, neither the admission phosphate level nor subsequent values were influenced by this mechanism, because none of our patients received glucose infusion during the study period.

To our knowledge, there are very few published data about serum phosphatemia in the acute phase of myocardial infarction, mostly from the era when mechanical reperfusion (i.e. primary percutaneous intervention) had not been used yet. Khetagurov et al. studied serum levels of phosphorus and calcium in patients with acute myo- cardial infarction during the initial phase of hospitalization [14]. Interestingly, patients with the lowest $\mathrm{Pi}$ and low variance of $\mathrm{Pi}$ had a better clinical outcome. Gould et al. described a significant decline of the serum phosphorus in the third and fourth postinfarction day as compared to the control group [13]. Conversely, the difference between groups on the first hospitalization day was not significant. They concluded that the serum phosphate was a sensitive indicator of myocardial infarction.

Interestingly enough, serum $\mathrm{Pi}$ in all our admission hypophosphatemic STEMI patients (21\% patients) returned to normal values within 6 hours without exogenous phosphorus administration. It has been shown that longer lasting hypophosphatemia may lead to clinically relevant consequences, e.g. heart, respiratory failure and arrhythmias $[1,2,8]$. Ognibene et al. found positive association between low phosphate and bicarbonate levels and the occurrence of ventricular tachycardia in myocardial infarction [18]. Vaidyanathan et al. investigated phosphate levels in acute MI patients and found the association between hypophosphatemia and left ventricular dysfunction as well as 30-day mortality [19]. On the contrary, in our STEMI group, we did not demonstrate a significant correlation between phosphatemia and peak serum troponin I levels.

In critically ill patients, hypophosphatemia might be associated with higher mortality but the evidence as to whether correction of hypophosphatemia improves the outcome is poor. There is a general agreement to reserve intravenous correction of hypophosphatemia for patients with associated symptoms or phosphate levels $<0.32 \mathrm{mmol} / \mathrm{l}[2,20]$. Zazzo et al. found a positive effect of hypophosphatemia correction on cardiac output in surgical intensive care patients [21]. We may only speculate on the possible effect of primary percutaneous coronary intervention on early serum phosphorus normalization as all our patients were treated in this way. Similarly, it cannot be inferred from our study, whether early rapid phosphate administration might be of any clinical benefit for selected acute MI patients with severe hypophosphatemia.

\section{Conclusions}

We conclude that patients with acute myocardial infarction with ST segment elevation treated by primary percutaneous coronary intervention have lower serum inorganic phosphate levels at admission and more frequent transient hypophosphatemia than acute cardiac care patients without acute coronary syndrome. Further studies are needed to better define the relationship between acute myocardial infarction and serum phosphorus levels.

\section{Acknowledgements}

Supported by the project Ministry of Health, Czech Republic for Conceptual Development of Research Organization 00669806 - Faculty Hospital in Pilsen, Czech Republic. 


\section{References}

[1] A. Gaasbeek, A.E. Meinders, Hypophosphatemia: an update on its etiology and treatment, American Journal of Medicine 118 (2005) 1094-1101.

[2] D.A. Geerse, A.J. Bindels, M.A. Kuiper, et al., Treatment of hypophosphatemia in the intensive care unit: a rewiew, Critical Care 14 (2010) R147.

[3] M.G. Betro, R.W. Pain, Hypophosphataemia and hyperphosphataemia in a hospital population, British Medical Journal 1 (1972) 273-276.

[4] L. Larsson, K. Rebel, B. Sörbo, Severe hypophosphatemia: a hospital survey, Acta Medica Scandinavica 214 (1983) 221-223.

[5] A.L. King, D.A. Sica, G. Miller, S. Pierpaoli, Severe hypophosphatemia in a general hospital population, Southern Medical Journal 80 (1987) 831-835.

[6] M.A. Camp, M. Allon, Severe hypophosphatemia in hospitalized patients, Mineral and Electrolyte Metabolism 16 (1990) 365-368.

[7] N.C. Bugg, J.A. Jones, Hypophosphataemia: patophysiology, effects and management on the intensive care unit, Anaesthesia 53 (1998) 895-902.

[8] J. Amanzadeh, R.F. Reilly Jr., Hypophosphatemia: an evidence-based approach to its clinical consequences and management, Nature Clinical Practice Nephrology 2 (2006) 36-148.

[9] L.R. O'Connor, W.S. Wheeler, J.E. Bethune, Effect of hypophosphatemia on myocardial performance in man. The New England Journal of Medicine 297 (1977) 901-903.

[10] R. Shor, A. Halabe, S. Rishver, et al., Severe hypophosphatemia in sepsis as a mortality predictor, Annals of Clinical and Laboratory Science 36 (2006) 67-72.

[11] R. Narang, D. Ridout, C. Nonis, J.S. Kooner, Serum calcium, phosphorus and albumin levels in relation to the angiographic severity of coronary artery disease, International Journal of Cardiology 60 (1997) 73-79.
[12] M. Tonelli, F. Sacks, M. Pfeffer, et al., Relation between serum phosphate level and cardiovasular event rate in people with coronary disease, Circulation 112 (2005) 2627-2633.

[13] L. Gould, C.V. Reddy, C.R. Swamy, et al., Decline of serum phosphorus in acute myocardial infarction, Angiology 30 (1979) 219-222.

[14] A.D. Khetagurov, Changes in the calcium and inorganic phosphorus of the blood in patients with acute myocardial infarct developing after coronary thrombosis, Terapevtichesky Arkhiv 35 (1963) 15-20.

[15] S.E. Kjeldsen, A. Moan, J. Petrin, et al., Effects of increased arterial epinephrine on insulin, glucose and phosphate, Blood Pressure 5 (1996) 27-31.

[16] A.A. Gomaa, H.A. Hassan, S.A. Ghaneimah, Effect of aspirin and indomethacin on the serum and urinary calcium, magnesium and phosphate, Pharmacological Research 22 (1990) 59-70.

[17] M.S. Buckley, J.M. Leblanc, M.J. Cawley, Electrolyte disturbances associated with commonly prescribed medications in the intensive care unit. Critical Care Medicine 38 (Suppl 6) (2010) S253-S264.

[18] A. Ognibene, R. Ciniglio, A. Greifenstein, et al., Ventricular tachycardia in acute myocardial infarction: the role of hypophosphatemia, Southern Medical Journal 87 (1994) 65-69.

[19] D. Vaidyanathan, S. Venkatesan, V.K. Ramadesikan, Serum phophate in acute myocardial infarction, Indian Journal of Physiology and Pharmacology 44 (2000) 225-258.

[20] D.W. Miller, C.M. Slovis, Hypophosphatemia in the emergency department therapeutics, American Journal of Emergency Medicine 18 (2000) 457-461.

[21] J.F. Zazzo, G. Troché, P. Ruel, J. Maintenant, High incidence of hypophosphatemia in surgical intensive care patients: efficacy of phosphorus therapy on myocardial function. Intensive Care Medicine 21 (1995) 826-831. 